\title{
ON THE SOCIAL HISTORY OF STEAM-POWERED GARDENS IN BERLIN AND POTSDAM
}

\begin{abstract}
When thinking about the historic landscape gardens of the Berlin-Brandenburg region we tend to focus automatically on the royal gardens that Peter Joseph Lenné originally included in his beautification plan for the Potsdam area that are now a UNESCO World Heritage Site. There is good reason for this focus. The complex of Sanssouci, Charlottenhof, Neuer Garten, Babelsberg, Glienicke, and Pfaueninsel constitutes an extraordinarily beautiful panorama. But from a broader perspective the unique character of these gardens can be seen to have informed the garden landscape of all of Berlin in a series of social transformations that occurred during the course of industrialisation in the nineteenth century. For this purpose it is useful to focus on the role of steam power. By no means, however, did the significance of steam power (or the lack of it) end with its utilitarian function, for it informed the aesthetic character of landscape gardens, too. And this character changed with the historical transformations that associated different sorts of gardens with people in different social strata. I will schematise three such »classes« of people and gardens.
\end{abstract}

Wenn wir an die historischen Landschaftsgärten in der Region Berlin-Brandenburg denken, fallen uns automatisch die von Peter Joseph Lenné in seinen »Verschönerungsplan für die Insel Potsdam« aufgenommenen königlichen Gärten ein, die heute zum UNESCOWeltkulturerbe gehören. Dafür gibt es gute Gründe. Der aus Sanssouci, Charlottenhof, Neuer Garten, Babelsberg, Glienicke und Pfaueninsel bestehende Komplex ist ein Panorama von außergewöhnlicher Schönheit. Aus einer breiteren Perspektive betrachtet wird jedoch deutlich, dass der einzigartige Charakter dieser Gärten die Gartenlandschaft von ganz Berlin in einer Zeit sozialer Umwälzungen beeinflusste, die im Zuge der Industrialisierung des 19. Jahrhunderts auftraten. Hierfür ist es hilfreich, die Rolle der Dampfkraft näher in den Blick zu nehmen. Die Bedeutung der Dampfkraft (oder das Nichtvorhandensein derselben) lässt sich dabei nicht auf deren bloßen Nutzen einschränken; vielmehr leistete diese selbst einen Beitrag zum ästhetischen Charakter der Landschaftsgärten. Dieser ästhetische Charakter wiederum veränderte sich im Zuge der historischen Umwälzungen, 
1 Karl Friedrich Schinkel, Charlottenhof, 1858.

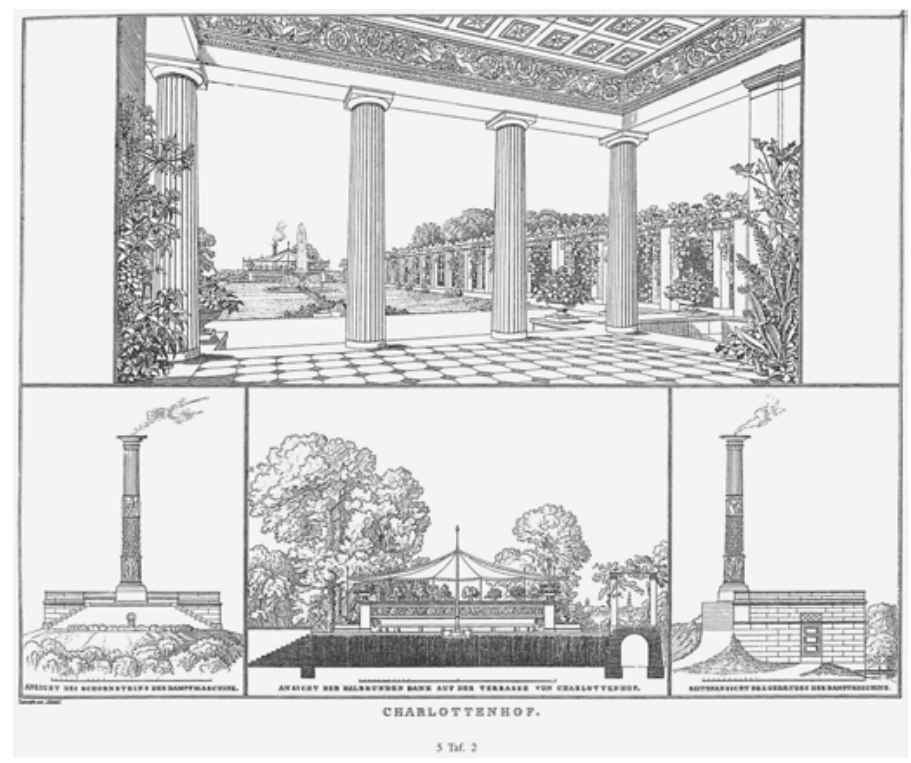

die verschiedene Arten von Gärten mit Menschen verschiedener sozialer Zugehörigkeit in Verbindung brachten. Ich werde drei solcher »Typen« von Menschen und Gärten im Überblick skizzieren.

\section{Royal gardens and an aesthetic of power}

It is not often enough remarked on that all of the great landscape gardens around Potsdam depended on steam engines to drive pumps that supplied water for irrigation, fountains and other»Wasserkünste«. Topography and geology are the reasons for this dependence. Despite being shaped by the spreading waters of the river Havel, the flat landscape of the region offered no streams running down hillsides to supply water at higher elevations, as was common in the traditional »English « landscape garden that the Potsdam gardens emulated. Equally important, the last ice age had left behind enormous quantities of sand over much of the area, requiring frequent irrigation to support diverse vegetation. Pumping engines thus compensated for the constraints of both topography and geology. But these technologies were also integrated into aspects of cultural expression in the gardens and palaces around Potsdam.

One such aspect was the social/political power of the royal family, which was sometimes expressed in surprising forms. A subtle example is Charlottenhof, the small summer residence of Crown Prince Friedrich Wilhelm, built in 1826-1828 from designs by Lenné and Karl Friedrich Schinkel with extensive input from the Crown Prince himself. Fig. 1, looking out from the portico of the palace across the terrace and central fountain, shows 
the longitudinal design, anchored at its eastern end by the gently smoking chimney of a steam engine. Like the Prince himself, Schinkel emphasised its significance in separate drawings, presenting it as a Roman candelabrum with an acanthus leaf motif and placed on an altar-like base (which housed the engine and served as a viewing platform over a large pond). The candelabrum is significant not only because it complements the neo-classical architecture of the palace but because ever since the Renaissance such candelabra had acquired a ubiquitous presence in Christian religious symbolism, with the flame and body of the candle typically representing the spirit and flesh of Jesus as the light of the world. ${ }^{1}$ Raphael, for example, expressed this iconography of spiritual power in his Madonna of the Candelabrum.

At Charlottenhof the Roman candelabrum with acanthus leaves was a unifying theme. If in the east, the chimney of the steam engine suggested the rising sun, in the western entry hall the candelabra on the twin stairways lit the darkness of the setting sun and night, as represented by blue windows carrying a field of stars. In the main bedroom, a pair of tall candelabra topped by the Prussian eagle stood at the foot of the bed with Raphael's drawings of Jesus, Moses and Elijah at the head. For the devoutly religious Crown Prince and his wife Elizabeth the candelabra apparently embodied the intimate relation of the power of Christianity with the divine right of the Prussian monarchy. To employ the same image for the chimney of the steam engine suggests an allegorical extension of royal power to the power of the engine to beautify and enliven the landscape (Wise 2014).

This power of steam was new in Prussia. When in 1824 the first engine to power a royal garden was installed at the Pfaueninsel it had to be imported. Two years later the small 6-8 hp engine for Charlottenhof came from one of the first engine builders in Berlin, Franz Anton Egells. The steam-powered garden thus emerged at the very beginning of industrialisation and at the top of the social spectrum, where the aesthetics of royal prerogatives took on new forms.

This theme has other, less subtle expressions. When the Crown Prince ascended the throne as Friedrich Wilhelm IV in 1840 he immediately launched a variety of projects to emblematise his rule. At Sanssouci that meant succeeding where Frederick the Great had failed, to make the 18th-century fountains spring to life and to extend them throughout the garden (Köhler 2014). This he did with the power of steam, in triumphant fashion. His central geyser at full pressure could now rise to $40 \mathrm{~m}$, as high as the dome on the palace. Ultimately 62 fountains of all types, along with standpipes for irrigation in sensitive areas, would reshape the landscape of Sanssouci and Charlottenhof.

Behind this accomplishment stood the most advanced engine in Prussia, built by August Borsig, who had worked with Egells for 10 years before launching his own machine works in 1837 . The $80 \mathrm{hp}$ engine could drive 14 pumps simultaneously to raise water from

1 For Berlin, an extravagant later display of Christianised Roman candelabra, both singly and in pairs, appears in the altar area and crypt of the Berliner Dom, for which I thank Christoph Markschies. For the analogous Roman use in temples and tombs, see Moses 1814, 37-43. 


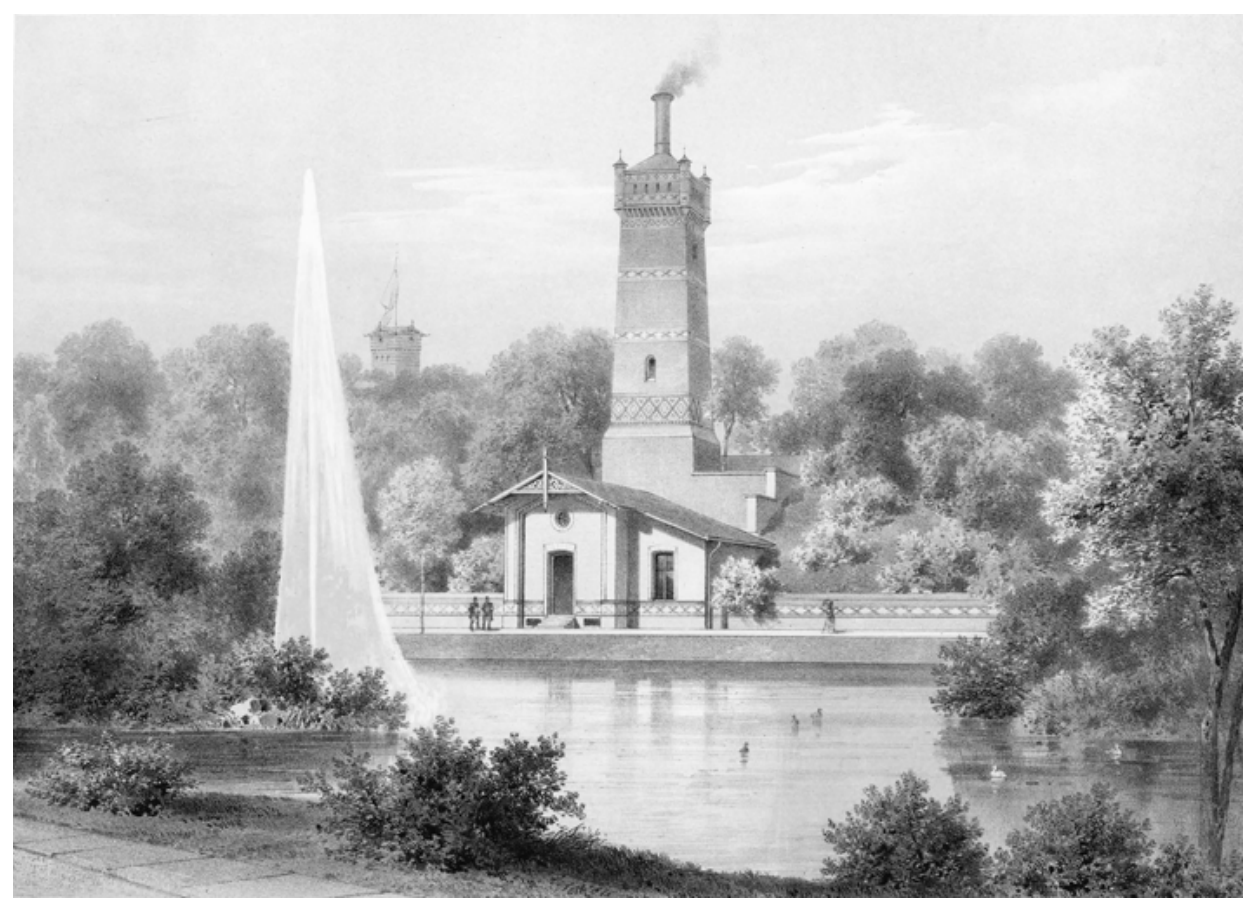

2 Hermann Ende and Wilhelm Böckmann, Dampfmaschinenhaus auf Wilhelmshöhe bei Berlin, 1871.

the river Havel to a large reservoir on the Ruinenberg behind the palace. On the order of the new king, the architect Ludwig Persius, who had supervised construction at Charlottenhof, housed the engine in forms resembling a mosque with a minaret for a chimney. The machinery extended high into the dome where the Prussian eagle stood atop its governor. Once again, Friedrich Wilhelm shaped his aesthetic sensibilities to represent the power of engines as an exotic new kind of spiritual and monarchical power, which could reshape the premier garden of the state.

It should be emphasised that the new steam-powered gardens of the royal family emerged as a direct product of the onset of industrialisation. That realisation shifts their origin from the green landscape of the Havel to a gritty area of Berlin known as »Feuerland», where Borsig established his plant next to Egells in 1837 just outside Oranienburgertor, and where during the 1840 s he became the "Lokomotivenkönig « for the rapidly expanding Prussian railroads. But many others also built their machine works in this area (Fig. 2), running north parallel to the Stettiner Bahnhof (now Nordbahnhof), which opened in 1842, and up to the later Volksgarten of Humboldthain. Relocating the engines to this area opens up different historical dynamics and a conception of the landscape garden rooted in the needs and interests of a completely different social class. 


\section{»Volksgärten« and an aesthetic of health and freedom}

The machines and engines of »Feuerland " powered the industrialisation of Berlin. In the same way they also resulted in rapid population growth, from 200,000 in 1820 to 400,000 by 1845 and then, after a period of slow growth through the 1850 s, in a steep rise to almost 2 million by 1900 . The social problems of housing, hunger, and disease that accompanied this expansion have been much discussed. It is nevertheless interesting to see how closely, literally, the production of engines was bound up with the emergence of new kinds of people. Next to »Feuerland « was the area called »Voigtland « (Plate IV, pink). It was also just outside the city walls and known as the poorest area and the victim of virtually uncontrolled speculation in the construction of housing blocks for the working people, the »Mietskasernen«. The so-called »Familienhäuser» of Kammerherr Heinrich Otto von Wülknitz, built in 1820-1824, were infamous for their squalid conditions. They were located just to the east of where Egells and Borsig built their plants and next to Carl Hoppe, another machine builder who started off with Egells.

»Mietskasernen « typically featured a four or five storey »Vorderhaus « on the street front with comfortable apartments at relatively high rents. »Seitengebäude« then stretched back into the site with several connecting "Quergebäude « separated by dim »Höfe«. Generally, the farther back and higher up one lived the lower the rent and the more meagre the accommodation (Reich 1912, 77-81; Skoda 1985). The hierarchy of rents likewise represented a hierarchy of working people, running downward from master craftsmen and journeymen of the traditional guilds through factory workers and servants.

The »Mietskaserne « lent a rather sharp definition to the living conditions that badly affected working people in north and east Berlin. Most obvious is space. In overcrowded apartments, averaging 5-7 people per room and less than $6 \mathrm{~m}^{2}$ per person, there was no free space. The same applies to light. Most apartments were as dim as the courtyards that separated the buildings. And stale air along with the non-existence of green spaces that could improve air quality were a constant complaint. But above all, as social historians have long emphasised, the "Arbeiter, « the factory workers, lacked control over their own time. »Free time« came to be in sharp contrast to factory time (Thompson 1967; Kocka 2015, 306-314). Space, light, air, greenery, and time: all of these unfulfilled desires came together in the positive concept of the "Volksgarten», the garden of the people, the garden of recuperation, freedom and health.

Lenné captured these ideas in concluding his famous 1840 proposal for the »Projectirte Schmuck- und Grenzzüge « for the city of Berlin. Identifying the overcrowded areas of the north and east as the "Hauptsitz der Gewerbe treibenden Klasse " he lamented the fact that they offered no green spaces at all to satisfy what he called the »Recht « of their residents to simply take a walk for relaxation: "wo der fleissige Handwerker, der tätige Fabrikarbeiter nach überstandenem Tagewerk sich abends und Sonntags ergehen könnte.« The creation of such spaces, he emphasised, had to be »dringend empfohlen « in the name of pleasure and especially of health (Lenné 1840, 184f.). The »Stadtverordnetenversammlung « agreed and 
over the next five years acquired 40 hectares for a Volksgarten at Friedrichshain (Plate V, green), located in the northeast just outside the city walls between Königstor and Landsbergertor. Gustav Meyer, protégé of Lenné and fast-rising star of garden architecture, won the design competition that led to the first »Volksgarten» in Berlin early in 1848.

The immediate context for this new form of landscape garden says much about its social role and its aesthetic character. Most immediately noticeable in the area around Friedrichshain are the many cemeteries of the local church parishes (in pink). There is nothing unusual about this in the sense that from 1794 all cemeteries were required to be outside the city walls. But one cemetery, located inside the garden (in red), was immensely important in social/political terms. Buried there were the bodies of the "Märzgefallenen«, killed on the streets of Berlin on March 19-20 during the revolution of 1848. The »Trauerzug« of at least 20,000 people stretched over 7 kilometers from the Gendarmenmarkt in the centre of the city all the way to Friedrichshain. People from every echelon of society were there, including a contingent of professors and students from the University led by the Rector and Alexander von Humboldt, popular with this diverse public for the liberal democratic positions that he represented at court as the king's chamberlain. More representative, however, were groups of workers and particularly craftsmen who paraded under the flags of their guilds and carried the coffins of their comrades. Borsig walked at the front of the workers from his plant, as did Egells and other owners of the engine and machine works of »Feuerland «. Out of the 270 people ultimately identified, 245 were craftsmen (mostly journeymen), workers, and servants (Wolff 1851, 322f.; Hoppe/Kuczynski 1964). Ever more the cemetery became a site of demonstrations for political freedom that added their stamp of protest to the Volksgarten.

Another such social stamp is apparent in the many institutions for the care of the poor (in yellow) that were located in the area. In addition to a cemetery for the poor, they included a shelter for the homeless, a mission house, a women's prison, and a large space excised from the potential garden area that was initially set aside for an orphanage. Concern about its proximity to the revolutionary symbolism of the "Märzgefallenen " prevented its construction. Ultimately the space would become the site of the first city hospital in Berlin (1874). Its ground-breaking design was inspired by Rudolf Virchow, known for his work in medical modernisation and as a leading political liberal. Complementing the concept of the "Volksgarten « itself, he identified fresh air as the first requirement for health, stating in a lecture at the Berliner Handwerker-Verein in 1869 that our task is: »Spitäler mit guter Luft zu bauen [...] Also vor Allem gute und reichliche Luft! Sodann gutes und reichliches Wasser und gute Nahrungsmittel! Das hilft in vielen Fällen mehr, als alle ärtzliche Kunst « (Virchow 1869, 26, 28). The new hospital would mainly serve the poor. Over $70 \%$ of its patients could not pay for their care.

The breweries (bright blue) that surrounded Friedrichshain are a final contextual element that helps to characterise it. These were very large commercial breweries: Patzenhofer, Böhmisches, and Lipps. They employed large numbers of workers and depended on industrial machinery and steam engines for their operation. They also featured large beer gardens that 
functioned effectively as extensions of the »Volksgarten « itself, where thirsty visitors could extend their walk »im Freien « with further relaxation and socialisation under the trees.

In short, the context of Friedrichshain reinforced its original conception as a space for working people, many of them quite poor, to express their right to health and freedom. To achieve these goals in the garden itself Meyer designed a landscape that emphasised »Gelegenheit zur Bewegung, zum Genuss des Freien, « with many miles of walking paths. They followed the traditional gently curving form but were wider and more densely arrayed to accommodate the expected throng of workers seeking recuperation during their free time from the draining labour of their daily lives. As they strolled along, broad grassy areas with few trees enhanced the sense of openness while a wide variety in the vegetation and the continual play of light and shade stimulated the senses and the imagination. As Meyer put it, the character of a »Volksgarten» should consist more in »Grösse und Freiheit « than in "Zierlichkeit und Abgeschlossenheit." Of major significance for working families were children's playgrounds (left centre) and a gymnastics exercise ground (top centre), previously unknown in landscape gardens (Meyer 1860, 36f.; Schmidt 2004, 63-85). What were missing, however, were the expressions of elite culture familiar in the royal gardens, whether as mythological sculptures, monuments, teahouses, follies, or classical architecture. But what were most noticeably missing were fountains, streams and other "Wasserkünste« powered by steam engines built into elegant and exotic houses.

Meyer did include two pieces of water in the form of natural ponds where the water table reached the surface. The smaller and deeper one (blue) was home to water lilies, frogs, and small fish. The larger one (tan) was actually less a pond than a wetland that dried out in the summer, especially when the steam engines of the neighbouring breweries and the hospital had begun pumping large quantities of water from deep wells, thereby lowering the water table (Stoll 1881, 4, 11). Complaints from botanists and appeals for an artificial supply - i.e. a pumping engine - produced no action. Ironically, the people whose very existence in the city and whose identities as »Arbeiter « depended most directly on the power of steam for industrialisation did not find, in a garden dedicated to their needs, the simplest enhancements available from engines.

Their needs, however, received attention through the addition in 1864 of a large flat area (not coloured) east of the original garden. This "neue Hain, " again designed by Meyer, served partly pedagogical purposes. It contained only native trees and shrubs with botanical sections to supply educational material for Berlin schools. But its main attraction was the large hippodrome-like Spiel- and Sportplatz in the centre. »Der weite, grüne Plan ist von hunderten fröhlicher Kinder belebt [...] [wo] ein Teil der männlichen Jugend Berlins hier unter Aufsicht von Lehrern seine Spiele abhält.« »So findet die Jugend hier eine Stätte der Erholung und daneben Gelegenheit, zu lernen und die Kenntnisse zu erweitern. Erziehung und Unterricht greifen hier in einander und wirken veredelnd und bildend auf Geist und Gemüt ein« (Stoll 1881, 14).

In Friedrichshain the aristocratic landscape garden has been transformed into a true »Volksgarten», intended now to express an aesthetic of health and freedom. Its qualities 
were defined by the contrast between the garden and the living conditions of the "Mietskaserne" and the working conditions of the factory. Open space, the play of light, fresh air, ever-renewing greenery, playgrounds, and exercise grounds aimed to nurture a sense of physical and mental health and the attractions of education, all bound up with the liberating experience of »free time." This sense of personal health and freedom found a common footing in the liberal pursuit of political freedom and the rights of working people.

\section{»Villenkolonien« and an aesthetic of attainment}

If the Revolution of 1848 serves as a marker for recognition of a new social class of »Arbeiter « and for a new garden serving their needs, then the »Gründerzeit« of 1870-1873 marks a similar watershed for a newly well-off middle class - also a product of industrialisation - and for another new form of landscape garden, the »Villenkolonie«. This story has a prelude among actual titans of industry like August Borsig whose great wealth enabled them to emulate something of the character of aristocratic and royal gardens. Already highly successful, Borsig in 1849 established in the industrialised area of Moabit a massive iron works on the banks of the Spree. Immediately adjacent he built his own villa with a garden designed by Lenné spanning some three and a half hectares. In addition to a fountain and stream maintained by steam engines from the plant, it contained greenhouses warmed by their cooling water along with ponds and a palm house for tropical vegetation. In a specially designed »Victoria House« he brought to bloom for the first time in Berlin the giant water lily Victoria Regia. This juxtaposition of iron works and garden aesthetics may serve as an icon for the historical dynamics of landscape gardens in Berlin.

Other examples can be cited of the penchant of great industrialists to own their own steam-powered gardens. The »Eisenkönig « Ludwig Friedrich Jacob Ravené also incorporated a steam engine for the fountains of his garden in Moabit, while Werner Siemens of telegraph fame put an engine in the basement of his new villa in Charlottenburg to keep water flowing in a large pond. But these were some of the richest men in the city. Very few others could afford such luxury. Nevertheless, the desire to mark, by means of a lush garden, one's arrival among the economically and culturally successful was widespread.

Gustav Meyer apparently already recognised this desire and the constraints it involved in his Lehrbuch der schönen Gartenkunst of 1860. There he included designs for five small gardens. Two of them he placed next to small factories whose excess engine power could supply their »Wasserkünste«, perhaps with Borsig in mind. Two others are so small, only $1 / 3$ hectare, that they seem to defy the very concept of a landscape garden (Meyer 1860, Tafeln XVIII, XIX). Conceivably, Meyer may have seen in these images the possibility for a larger development of multiple villas, each on a small parcel of land and all powered by a single steam engine, with the whole conceived as one garden. In any case, that is the new form that took off around 1870 as the »Villenkolonie«. 
An example that captures the idea visually is the 1871 design for the colony of Wilhelmshöhe (Fig. 2) next to the current Victoria Park in Kreuzberg. The engine house and water tower, along with the beautifully landscaped pond and fountain, all suggest elements of the royal gardens around Potsdam, as does the name Wilhelmshöhe itself, referencing the great landscape garden in Kassel. Built on a former sand quarry, the colony needed the engine and water tower for irrigation as well as »Wasserkunst «. Starting from a plan by Lenné himself, the architects Hermann Ende and Wilhelm Böckmann originally drew up plans for 40 villas on the small site but that number was reduced to a more modest 20 villas laid out on a gated private street. One of the most notable characteristics of this and other such colonies is their integration as a single entity, an integration announced by the common engine house and water tower, and in this case by the central pond and fountain. This integration also helped to convey an aesthetic of attainment, of exclusivity, community, and self-representation among those who had achieved economic well-being.

A much larger colony intended for only moderately well-off citizens is Westend, named (rather hopefully) after the fashionable area of the West End in London. It was founded in 1866 by Albert Werkmeister and designed by Martin Gropius as a gridded community containing about 350 parcels, located just west of Charlottenburg. Westend owed its existence once again to the capacity of a steam engine to pump water from deep wells and transform an area of largely bare sand into a green oasis laid out on streets named after native shade trees: oak, elm, maple, cherry, linden and plane. On one of these plots there was an engine house and water tower which supplied the water piped to each villa. The villas themselves varied greatly, from fairly modest brick houses to elaborate mansions. No matter what their size, every villa featured its own garden which meant that, viewed as a whole, the colony formed a continuous area of trees, shrubs and grassy areas, notionally resembling a landscape garden.

The development of colonies like Westend occurred particularly during the »Gründerzeit « on the initiative of financiers seeking large profits from speculative investments. One of these entrepreneurs was Heinrich Quistorp who, with a consortium of investors, took over Westend in 1868 with ambitious plans for expanding the colony. The problem of course was water. To solve this problem, the Westend-Gesellschaft built in 1871-1873 a much larger pumping facility at the Teufelssee in the nearby Grünewald. Again the engine builders of »Feuerland» provided the necessary power, with a beautiful 150 hp engine made by the firm of Friedrich Wöhlert, who had worked originally with Egells and Borsig. With this great engine (Fig. 3) Quistorp intended to fill a huge reservoir that he had constructed in Westend in 1872-1873. He named it Germania to capitalise on the nationalist sense of unity and victory following the Franco-Prussian War. With a capacity of 3,000 $\mathrm{m}^{3}$ it was the largest reservoir of this kind known at the time. Quistorp intended to use it to extend his enterprise from Westend to Charlottenburg and to what he expected would be a fast-growing residential area in the southwest. Instead his Westend Gesellschaft went bankrupt in 1873 and water never flowed to Germania. But the engine at Teufelssee continued its operation and the Charlottenburger Wasser- und Industriewerke AG took it over in 1878 (Börsch-Supan/Haddenhorst 1997, 21-27). Throughout all these financial upheavals the wa- 

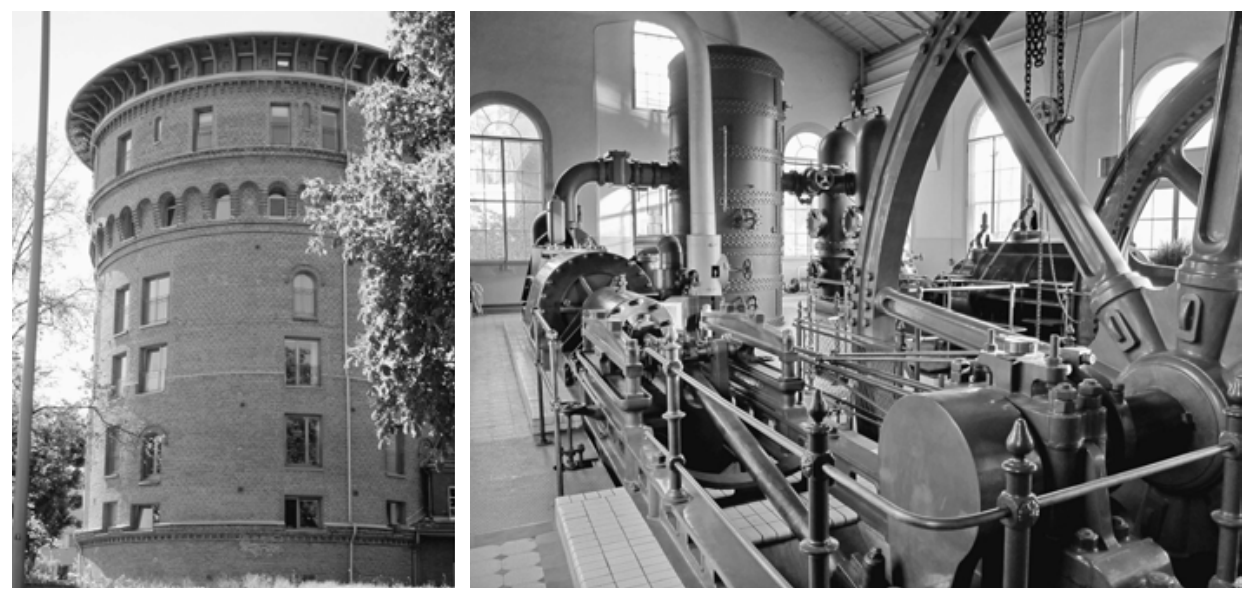

3 Westend water tower, 1882, and Teufelssee engine from Wöhlert, 1873.

ter towers continued to be the identifying symbol of the colony as a unit, with new ones built in 1882 (Fig. 3) and 1909 to satisfy the continuing thirst of its villas and gardens.

Perhaps few property owners in Westend explicitly recognised that the source of »value« in their properties, both monetary and aesthetic, flowed from the water towers and the engine at Teufelssee. They did, however, recognise that they lived in a relatively exclusive colony together with other successful citizens. This appealed not only to business people but also to the administrative, professional, and cultural elite of Berlin, the "Bildungsbürgertum ", who distinguished themselves through their educational and artistic attainments. By about 1900 these residents included microbiologist Robert Koch, sociologist Georg Simmel, astronomer Wilhelm Foerster, historian Otto Hinze, sculptor August Vogel, painters Sabine and Reinhold Lepsius and poet Stefan Georg.

\section{Conclusion}

Over the course of the nineteenth century in Berlin the landscape garden underwent several transformations. I have identified three such transformations that were closely associated with industrialisation, with the steam engines that powered it, and with the classes of people it successively affected or spawned. Issues of sand and water table always provided the "arena « in which these transformations were played out. But I wished to outline how the engines (or lack of them) affected the character of the landscape garden in its different social forms.

These are not characteristics of which we are usually conscious today. Visitors walking in the formerly royal gardens around Potsdam no longer »see « the various powers that they once signified. Similarly, the Volksgarten of Friedrichshain, though still a haven for the working classes, now signifies freedom and health for a much broader social spectrum of 
Berliners. It even includes ponds and fountains where previously no water flowed. Finally, the many »Villenkolonien « that sprang up in the southwest (Lichterfelde, Wannsee, Schwanenwerder, Neu Babelsberg, etc.) are now suburbs, more or less wealthy, with nothing like the sense of an integrated community in a single landscape garden that their engine houses and water towers once expressed.

Despite all these social and cultural changes, in the current era of climate change water and sand still constitute the underlying problematic of landscape gardens in Berlin. And the significance of the gardens continues to depend on the social context. With the diversity of this context in mind, a pressing question remains: what aesthetic forms will landscape gardens assume under climate change?

\section{Bibliography}

Börsch-Supan, Helmut; Haddenhorst, Michael (1997): Westend. Berlin: Nicolai.

Hinz, Gerhard (Hg.) (1937): Peter Joseph Lenné und seine bedeutendsten Schöpfungen in Berlin und Potsdam. Berlin: Deutscher Kunstverlag.

Hoppe, Ruth; Kuczynski, Jürgen (1964): Eine Berufs- bzw. auch Klassen- und Schichtenanalyse der Märzgefallenen 1848 in Berlin. In: Jahrbuch für Wirtschaftsgeschichte 4, 214-272.

Kocka, Jürgen (2015): Arbeiterleben und Arbeiterkultur. Die Entstehung einer sozialen Klasse. Bonn: Dietz.

Köhler, Marcus (2014): Sanssouci Park from a Mythological View: Or - Borneo at the End of Hauptallee. In: The Pleasures of Royal Gardening in Sanssouci Park. Design, Cultivation, Enjoyment. Berlin: Deutscher Kunstverlag, 9-23.

Lenné, Peter Joseph (1840): Erläuterung zum Projekt »Projectirte Schmuck- und Grenzzüge von Berlin mit nächster Umgegend. « In: Hinz (Hg.) (1937), 177-185.

Meyer, Gustav (1860): Lehrbuch der schönen Gartenkunst. Berlin: Riegel.

Moses, Henry (1814): A Collection of Antique Vases, Altars, Paterae, Tripods, Candelabra, Sarcophagi, \& c. London: Bohn.

Reich, Emmy (1912): Der Wohnungsmarkt in Berlin von 1840-1910. München/Leipzig: Duncker \& Humblot.

Schmidt, Erika (2004): »Abwechselung im Geschmack« Raumbildung und Pflanzenverwendung beim Stadtparkentwurf. Deutschland 19. Jahrhundert. Zittau: Graphische Werkstätten.

Skoda, Rudolph (1985): Das »Voigtland«: Wohnhäuser und Wohnverhältnisse der Stadtarmut in der Rosenthaler Vorstadt von Berlin 1750-1850. Berlin: Kulturbund der DDR.

Stoll, Carl (1881): Der Friedrichshain bei Berlin seine landschaftlichen Schönheiten und seine Bedeutung für das Studium der Botanik. Berlin: Nicolai.

Thompson, Edward P. (1967): Time, Work-Discipline and Industrial Capitalism. In: Past \& Present 38.1, 56-97.

Virchow, Rudolf (1869): Über Hospitäler und Lazarette. Berlin: Lüderitz’sche Verlagsbuchhandlung.

Wise, M. Norton (2014): Wasser als Kunst in den Parks - Mithilfe von Dampfmaschinen. In: Historische Gärten im Klimawandel. Empfehlungen zur Bewahrung. Hg. von Michael Rohde. Leipzig: Edition Leipzig, 174-179.

Wolff, Adolf (1851): Darstellung der Berliner Bewegungen im Jahre 1848 nach politischen, socialen und literarischen Beziehungen, Bd. 1. Berlin: Hempel.

\section{Picture Credits}

1 Schinkel, Karl Friedrich (1858): Sammlung Architektonischer Entwürfe. Berlin: Ernst \& Korn, Tafel 110; 2 Architektonisches Skizzenbuch 107, 3; 3 Norton Wise.

Plate IV Staatsbibliothek zu Berlin, Preußischer Kulturbesitz, Kart. X 17937, Bl. 2, 5; Plate V Staatsbibliothek zu Berlin, Preußischer Kulturbesitz, Kart. X 17937, Bl. 6. 
IV Maschinenbau

in »Feuerland « (orange):

1. Königliche Eisengiesserei (1804),

2. F. A. Egells (1826),

3. A. Borsig (1837),

4. F. A. Pflug (1839),

5. F. Wöhlert (1842),

6. C. Hoppe (1844),

7. L. Schwarzkopf $(1852,1867)$,

8. W. Wedding (1857);

and area of »Voigtland « (pink). Colors added to Liebenow, Wilhelm (1888):

Situations-Plan von der Haupt- und Residenz-Stadt Berlin und Umgegend. Berlin: Schropp.

V Friedrichshain (green) and its context: cemeteries (pink) with Märzgefallenen (bright pink), care of the poor (yellow), breweries (bright blue), small pond (blue), large dry pond (tan), playgrounds (tan). Colors added to Liebenow, W. (1888): SituationsPlan von der Haupt- und ResidenzStadt Berlin und Umgegend. Berlin: Schropp.
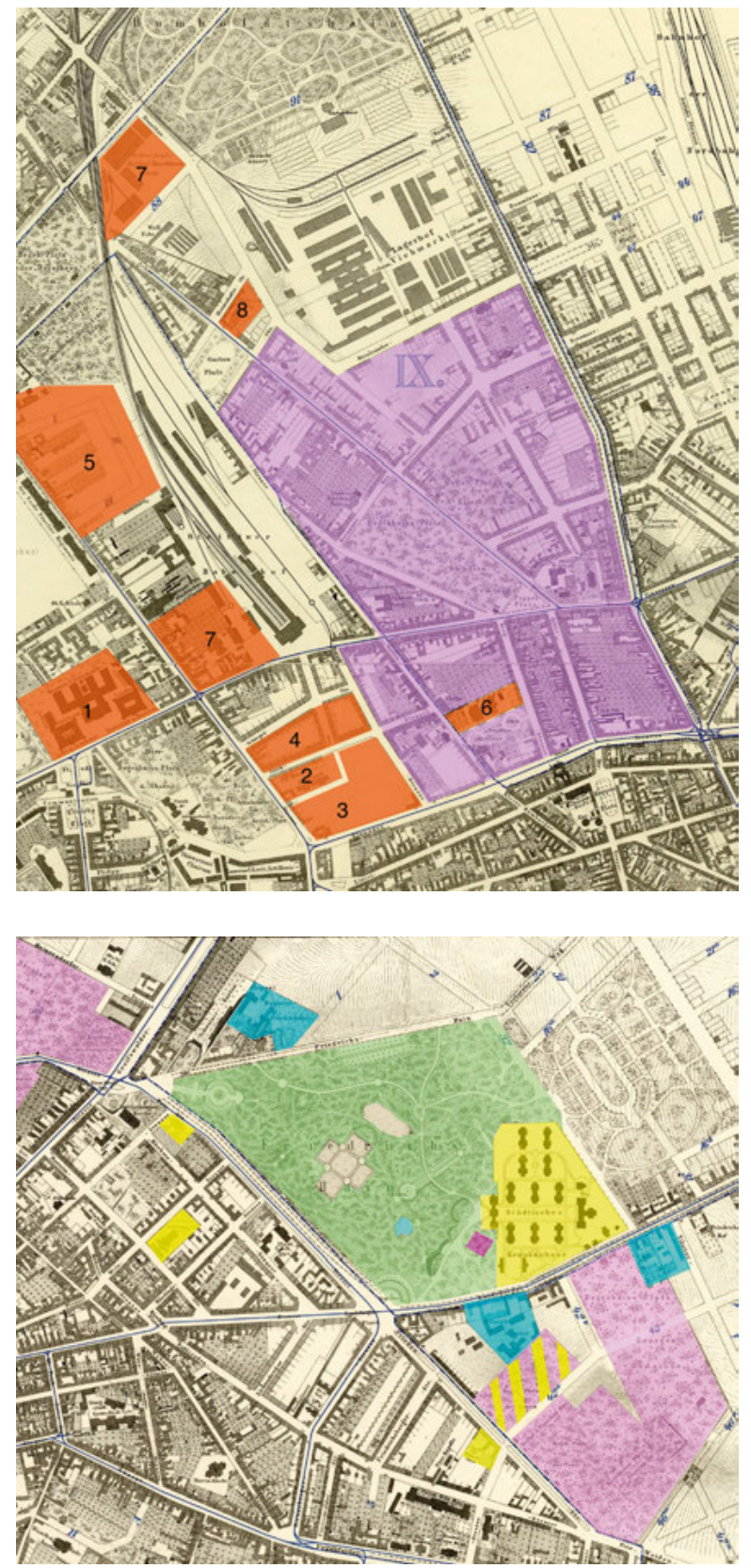